\title{
FROM AESTHETICAL TOWARDS ETHICAL: MYTH AND METAPHOR AS MODE OF NARRATIVE IN LEVINAS
}

\section{A B S T R A C T}

In this paper, I will try to show that Levinas's ethics contains the aesthetics of mythological narrative that has metaphorical ("as if" meaning) and archetypal dimension, while the relation between ethics and aesthetics will be explained by Levinas's perception of eros. These goals are based on the assumption that myth represents uroboric foundation of Levinas's philosophy by which he succeeded in getting rid of the egology of Western thought, but also from the experience of his own imagination. The myth speaks about universals through various representations, relations, characters, etc. Taking into account that universals are archetypes, and that all archetypes in history of mankind have aesthetic dimension, Levinas's philosophy „offers“ this archetypal structure of myth through its operational concepts such as eros, infinity, feminine, trauma, maternity, fecundity etc. I will try to show that Levinasian establishing of ethics as philosophia prima is based on language of metaphors and imagination as material and unknowable foundation of psyche. 
Levinas's work attempts to criticise the classic egology of Western philosophy (ontology); however, his criticism is also an effort of the aesthetic to overcome ontology. The aesthetics of Levinas's thought and its dimension of beauty, is supported by relics of religious mythology, so concepts in his work are also myths that tend to be processes for destruction of intentional consciousness. Returning to the field of ontology which performs violence against Other, Levinas is actually in mythical and non-historical narrative because his breakthrough to ethics is conditioned by reckon with archetypes of God and eros, love and feminine. Archetypes are collective apprehensions, that is, matrices and receptacles of collective apprehensions formed through various contents of culture. Archetypes, as well as myths, tend to be universal also through internal scenario of drama as struggle of hero, righteous man, wounded rescuer, etc.; all archetypes in the history of mankind have aesthetic dimension. It is reflected in dramatic narration that aims to show how collective should live and understand its existence. So, since these are products of collective psyche, archetypes and their narratives always give us a story about mythological heroes and gods who have attributes of justice, courage, endurance, ideal paternity, maternity, salvation, etc. In Levinas's philosophy, the archetypal basis of Hebrew monotheistic myth also speaks through its operational concepts (eros, justice, trace of infinite, feminine, trauma, maternity, paternity, fecundity etc.). All these concepts are clusters of monotheistic archetype of righteous God of Hebrew tradition. In order to present Levinas's effort that introduces ethics from language of aesthetics, I will look back at his understanding of eros and feminine, from which arises archetypal and mythological tension of his aesthetics and ethics.

In Levinas's work, understanding of eros is crucial because of discovery of one phenomenon: originality of sexual difference, as well as idea that transcendence of subject is fulfilled in eros. Numerous and exhaustive Levinas's descriptions of ambiguity of eros testify to presence of aesthetic in eros, which is reflected in effort to pronounce love, to describe universal love and to save the Other from philosophy as violence against him. Showing the language effort to reach the Other, through eros, Levinas does not only explain the uniqueness of this phenomenon, but introduces us into the ethics, by descriptions such as "transcendence, by power of love, goes simultaneously further and less far from language", "simultaneously on this side and beyond language", "ambiguity of an event that lies at the boundary between immanence and transcendence", "simultaneity of need and desire", "simultaneity of pleasure and transcendence", "simultaneity of mysterious and revealed", "vulnerability and inviolability", "touchiness and untouchability". ${ }^{1}$ 
Nevertheless, each of the descriptions given by Levinas points to the fact that eros does not have purely ethical character, but by introducing an "immanent", "voluptuous", "touchy", he introduces a passionate part of eros, which somehow places it on this side and beyond of being. As enjoyment of a beloved, erotic relating is return of subject to itself, and simultaneously is obligation towards beloved, the ethical transcendence towards him/her. So, at one point, Levinas, by determinating eros as imanent, claims that in its essential segment, eros is defined as the rejection of transcendence and the union with "soulmate", as "incest". Levinas justifies such strict interpretation of eros through rejection of transcendence - by enjoyment. Of course, this returning back, this entry into the need and returning to subject does not remain on it, but on the contrary, it always contains the transcendence of Other, always "presupposes total, transcendent exteriority of other, Beloved."

Levinas's aesthetics of thought is, therefore, contained in metaphors that are only linguistic figures and ornaments. Metaphor is a way of existence in ontological sense; however, in psychological terms, it is only a style of consciousness; it is a combination of unity and difference of psychological truths that are expressed through archetypal apprehensions. Metaphors are also rhetorical tool that enhances the affect of expressed, they represent "epistemic accretion", whose power can be seen in the following example: in afore mentioned ambivalence, erotic love refers beyond itself to dimension that is "beyond the face, which is expressed in a simple gesture of caress. Caress expresses desire that is focused on what 'is not yet', on expectation of pure future without content." And as pleasure, eros assumes a face; in other words, non-meaning of eros is based on meaning of face. In the second example, we find metaphor of light and face. Here again, Levinas's imagination tries to "overcome" images and apprehensions, in order to describe indescribable. This Levinas's aesthetic gesture is a distinct attempt to reach the unknowable.

But love also goes beyond the beloved. This is why through the face filters the obscure light coming from beyond the face, from what is not yet, from a future never future enough, more remote than the possible. An enjoyment of the transcendent almost contradictory in its terms, love is stated with truth neither in erotic talk where it is interpreted as a sensation nor in the spiritual language which elevates it to being a desire of the transcendent. ${ }^{4}$

Therefore, the basic terms in description of eros's ambiguity are Other, face, love, desire, etc. However, we cannot ignore the fact that myth is a fiction that denies its reality even when expresses it or calls upon it, but what is fictitiously in the myth is clothed in metaphors, and in Levinas's work, metaphors emerge 
through the notions and descriptions of vulnerability, traumatism, etc., which also introduce ethics and the Other in philosophy. But, mythical metaphors have "as if" character, which can be said for several Levinas's key concepts that he also wants to translate from aesthetic level of mythical representation into ethics: love, deity, mortality, trace of infinite ... And love/eros is, in some regards, a half way between the divinity and mortality. But what may be denoted as the most important here is that, on the one hand, eros is a "child" of need that stands on bare ground and is hungry, thirsty and homeless, while on the other hand, eros is a "child" of fullness, always looking for truth and always weaves some strategy. ${ }^{5}$ Although Diotime's speech in Symposium begins with adoption of Aristophan's identification of love with possession of everything that is good, it seems that later, when she said that love is not only a disadvantage, but as a ghost standing between the lack and possession, poverty and prosperity, she approaches to Levinas's conception of love. ${ }^{6}$ Abandoning Aristophan's characterisation of eros as a mere lack and poverty, Levinas sees the possibility of overcoming the contradiction between desire and need and the movement towards eros as a need in desire.

For Levinas, the erotic relation is exemplary ethical relation, since love is directed toward the Other, and that it has his/her weakness in mind. Levinas understands weaknesses not as some kind of Other's lack or his/her fault, but as something that qualifies the otherness itself, so he emphasises that "to love is to fear for another, to come to the assistance of his frailty." In eros, the original and absolute otherness of feminine is encountered; in eros, an exemplary relation to that otherness is realised, which gives it a special place among all relations. ${ }^{8}$ The other who is not simply revealed as face, but who is withdrawn and absent, who is discreet, fragile, vulnerable, shy, is feminine: "The simultaneity or the equivocation of this fragility and this weight of nonsignifyingness, heavier than the weight of the formless real, we shall term femininity." Feminineas Other offers a face that goes beyond the face. It is an ambiguous face - bleary and clear at the same time, and in whose meaningful character the non-meaning is maintained.

A contact with ambiguous erotic feminine, with gentle and fragile body is caress, in which also lies ambiguity. Caressing does not mean touching the way we touch any object; we can caress only other Face, we caress only Beloved one. Caress is the movement towards the invisible, and simultaneously it anticipates pure future. As a touching, caress is a sensuality, but it also transcends sensual content; it preserves the intention of hunger moving towards food, that is, it is feeding by its own hunger: caress aspires to what is incessantly withdrawn from its form toward future. There is no intentionality of discovery here, but a quest: a motion to the invisible. 
And in this case, the ambiguity on which Levinas insists, will additionally get stronger:

Reference of love 'given' to love 'received', love of love, voluptuosity is not a sentiment to the second power like a reflection, but direct like a spontaneous consciousness. It is inward and yet intersubjectively structured, not simplifying itself into consciousness that is one. In voluptuosity the other is me and separated from me. The separation of the Other in the midst of this community of feeling constitutes the acuity of voluptuosity. ${ }^{10}$

Feminine in Levinas illustrates the ambiguity that consists in alternation/ alternativeness between transcendence and immanence; it is a movement of bending into and out of being and otherness constitutive to being, but inaccessible to understanding, or to knowledge. On the one hand, there are series of allusions, as well as explicit claims that the concept of feminine should be read as incisive "metaphor", "tool", "notion", "situation", "event" or "category"; while on the other hand, especially in domains of home and dwelling, there are possibilities for reading according to which feminine refers to empirical gender or sex. Very characteristic are Levinas's descriptions of concept of feminine as unknowable, closed and withdrawn from light and light is a metaphor for disclosure and knowledge, for elusiveness. This characteristic is central for very erotic experience, and it is precisely that which leads Levinas to claim that his analysis is "not entirely phenomenological".

If we understand metaphors as perspectives, then it is clear that metaphor is the life-principle of all living languages. It is a verbal expression of processes and products of imagination and its power of creative synthesis. Metaphor is hence dynamic, synthetic and creative force of language that carries power to alterate reality. In this sense, the mythical narratives about woman/feminine, the other, the trace of infinite, etc., which Levinas tried to describe without totality (that is metaphor for completeness, and idea of completeness is an archetype, not a real reality), attempt to fill the space by overcoming of context: this filled space is both divine and human, but Levinas designates it by terms whose meaning wants to overcome too. Thus, the metaphoric reality is the capacity of seeing and passing through the data of Western thought into depths of Levinas's archetypal representations of infinity. The myth is "narrative form of understanding that implies continuous dialectic between the same and differentother, between memory and desire, between ideology and utopia, between hierarchy and horizon, between sacred and profane." Levinas' is only a bridge of mythic aesthetic for approaching ethical. 
Levinas' narrative is a curious effort of soul self-expression as experienced subject, but in a narrow sense, this narrative is its form and style of discourse that has an aesthetic dimension because it introduces mythological and archetypal images into description of ethical. His narrative is actually a structure that is inherent to Hebrew tradition, as well as to personal psychic actions and traumatic experiences. If we know that metaphors are "way of perceiving, feeling and being," 12 what is Levinas's metaphor of trauma in ethics telling us about? Namely, the condition of possibility for ethical relations lies in development or articulation of certain ethical language. Levinas develops ethical language that aims to express what he calls "the paradox in which phenomenology suddenly finds itself." The paradox here is that object which language wants to tematise, cannot be tematised, by definition: it is the conception of subject constituted in relation to the otherness which cannot be reduced to ontology, i.e. irreducible to thematisation or conceptuality. Ethics does not occur at the level of consciousness or reflection, but rather at the level of sensibility or preconscious sensitivity. Levinasian ethical subject is sensual self (un soi sentant) before it becomes an ego (un moi pensant); its meaning of unconscious as "the night in which the ego returns to the self under the traumatism of persecution" means that Levinas tries to think the subject at the level of unconscious in relation to one original traumatism. The subject is constituted through non-dialectical transference towards original traumatism. Without trauma there would be no ethics in Levinasian sense of the word. Levinas tries to encapsulate this disposition towards the other in the subject, by "termes éthiques" or even "un langage éthique": accusation, persecution, obsession, commutation, hostage, etc. These are metaphors by which, through traumatism, he tries to describe duty in relation to the other. The myth offers us the possibility that, through the imaginal place (archetopos) and divine characters (archetypes), we can understand Levinas's monotheistic ethics as polytheistic ontology, in which gods are not injured by other, but the man is wounded by familiar (Other).

Narrative provides context, discourse provides action. However, the structure examines both action and discourse, and hence the myth is the unity of mythical narrative and mythical-ritual being in world: the unity of mythological semantics and syntax. In Levinas, the terminology I claim is aesthetic, in nature is (in large extent) synonymous with phenomenological essentialism.

Interpreting Hölderlin's poetry, Heidegger writes that in the torment, man is permitted to look up into heavens - and looking upwards mesures that between heaven and earth. That between is measured for (hu)man's dwelling. A measured survey, through which that between the sky and the earth is 
open, Heidegger designated as dimension. But the essence of this dimension remains nameless. For Hölderlin, the essence of poetry is to take the measure of "(hu)man's measurement" and the very poetic creation is taking the measure of (hu)man's dwelling. For Hölderlin, dwelling poetically means living in presence of gods. Are these lines approaching to Levinas? How does Levinas describe our dwelling, or dimension under the sky? Could we say that the divine is measure for Levinas, as for Hölderlin when he describes poetry? Does dwelling ethically means living in presence of gods, especially when we know that ethics in Levinas's philosophy represents a path that leads on the other side of being, and that there is nothing that goes beyond ethics? Taking all of these into account, I shall dare and characterise Levinas's thought as a kind of poetic kingdom of Western philosophy and an incomprehensible attempt to describe the goodness and infinity we bear in the myths in our own souls.

Levinas, Totalitet i beskonačnost, 230.

Emanuel Levinas, Vrijeme i Drugo, trans. Spasoje Ćuzulan (Podgorica: Oktoih, 1997), 72.

Levinas, Totalitet i beskonačnost, 230-231.

Cf. Platon, Gozba ili O ljubavi, trans. Miloš N. Đurić (Beograd: Izdavačko preduzeće "Rad", 1964), $48-55$.

Cf. Francisco J. Gonzalez, "Levinas questioning Plato on Eros and maieutics," in Levinas and the Ancients, eds. Brian Schroeder and Silvia Benso (Bloomington and Indianapolis: Indiana University Press, 2008), 40-62.

Levinas, Totalitet i beskonačnost, 241. 
Coupe, Laurence. Myth. London and New York: Routledge, 1997.

Francisco J. Gonzalez, "Levinas questioning Plato on Eros and maieutics," in Levinas and the Ancients, eds. Brian Schroeder and Silvia Benso (Bloomington and Indianapolis: Indiana University Press, 2008), 40-62.

Hillman, James. Re-visioning Psychology. New York: Harper and Row, 1975.

Levinas, Emanuel. Vrijeme i Drugo. Translated by Spasoje Ćuzulan. Podgorica: Oktoih, 1997.

Levinas, Emanuel. Totalitet i beskonačnost. Translated by Spasoje Ćuzulan. Beograd: Jasen, 2006.

Platon. Gozba ili O ljubavi. Translated by Miloš N. Đurić. Beograd: Izdavačko preduzeće "Rad", 1964. 


\section{DA LI ĆE UMRETI MARINA ABRAMOVIĆ?}

\section{Svetlana Racanović}

Postupno, a zatim žestoko ubrzanje i diversifikovanje životnih i umetničkih izbora i angažmana reflektuje želju umetnice Marine Abramović da se u njenu performans mašinu usadi i stavi u pogon sila perpetumobilnosti. Toliko puta u njenom životu i radu opipavana i izazivana linija kraja, okončanja, nemanja-posle-toga, dakle, smrti, time se ne bi melanholično potvrđivala ali ni očajnički poricala niti divlje zauzdalavala, već bi se ta linija poslednjeg horizonta snažno zarotirala i umesto fatalne postala vitalna, umesto granične postala ciklična, ona koja (se) vraća, ona iz koje se biva (hiper)produktivnim. Različitim strategijama i praksama ona pokušava da zakrivi strelu vremena, da zakoči, uspori, poremeti, sabotira njegovu logiku. Ona želi da rekonstruiše, revitalizuje, podmladi, produži trajanje tela svoje umetnosti, tela umetnosti performansa i, konsekventno, sopstvenog biološkog tela posežući za različitim metodama i mehanizmima supstituisanja, tehničke multiplikacije, ekstenziranja, virtualizacije, pa i spektakularizacije sopstvenog tela i tela svoje umetnosti.

KLJUČNE REČI: MARINA ABRAMOVIĆ, PERFORMANS, EFEMERNOST, SMRT, PODMLAĐIVANJE TELA UMETNOSTI/ UMETNIKA, TRAJNOST

\section{OD ESTETSKOG KA ETIČKOM:}

\section{MIT I METAFORA KAO MODUS NARATIVA KOD LEVINASA Kristina Bojanović}

U ovom radu pokušaću da pokažem da Levinasova etika sadrži estetiku mitološke naracije koja ima metaforično ("kao da" značenje) i arhetipsku dimenziju, dok ću odnos između etike i estetike nastojati da objasnim posredstvom Levinasovog poimanja erosa. Ovi ciljevi zasnovani su na pretpostavci da mit predstavlja uroboričku osnovu Levinasove filozofije kojom je on uspeo da se otrgne iz egologije zapadne misli, ali i iz iskustva vlastite imaginacije. Mit govori o univerzalijama posredstvom različitih predstava, odnosa, likova itd. Imajući u vidu da su univerzalije arhetipovi, i da svi arhetipovi u istoriji čovečanstva imaju estetsku dimenziju, Levinasova filozofija "nudi" arhetipske strukture mitova kroz operativne pojmove poput erosa, beskonačnosti, ženskog, traume, materinstva, plodnosti... Pokušaću da pokažem da je Levinasovo uspostavljanje etike kao prve filozofije zasnovano na jeziku metafora kao gradivnog i nesaznatljivog temelja psihe.

KLJUČNE REČI: MIT, METAFORA, EROS, ETIKA, ESTETIKA, DRUGO, ŽENSKO

\section{AISTHETON (ČULNO OPAŽANJE) U VREME DRUŠTVENO-POLITIČKE KRIZE Nebojša Vilić}

Glavna namera ovog rada je da predloži način razumevanja odnosa između estetike i politike u misli Žaka Rensijea kao teorijskog instrumenta za primenu u konkretnoj situaciji protesta. Nadalje, protest će se uzimati samo kao društveni događaj uživo, ali i kao telesno iskustvo sa posledicama i rezultatima koji proizlaze iz toga. Polazeći od Rancijerovog stanovišta raspodele čulnog i načina na koji predmet bez glasa mora da dostigne svoje pravo na govor, ovaj rad se bavi nekolicinom tema prema kojima se može zaključiti da samo fizičko prisustvo tokom protesta daje mogućnost subjektu da taj čin oseti razumno. Ovo je prilično različit pristup telesnog razumevanju sveta i iskustava poznatih kao odnos umetnosti i estetike, označavajući aistheton i kao istovremenog nosioca značenja političkog. Studija slučaja korišćena za ovu primenu je takozvana Obojena revolucija, i „bojenje“ makedonske kapije u Skoplju, u Makedoniji.

KLJUČNE REČI: AISTHETON, KOLEKTIV, TELESNOST, REŽIM DOŽIVLJAJA, NEMI GOVOR, POLITIKA, PROTEST, RAZUMAN 